Terbit online pada laman web jurnal: https://ejurnalunsam.id/index.php/jicom/

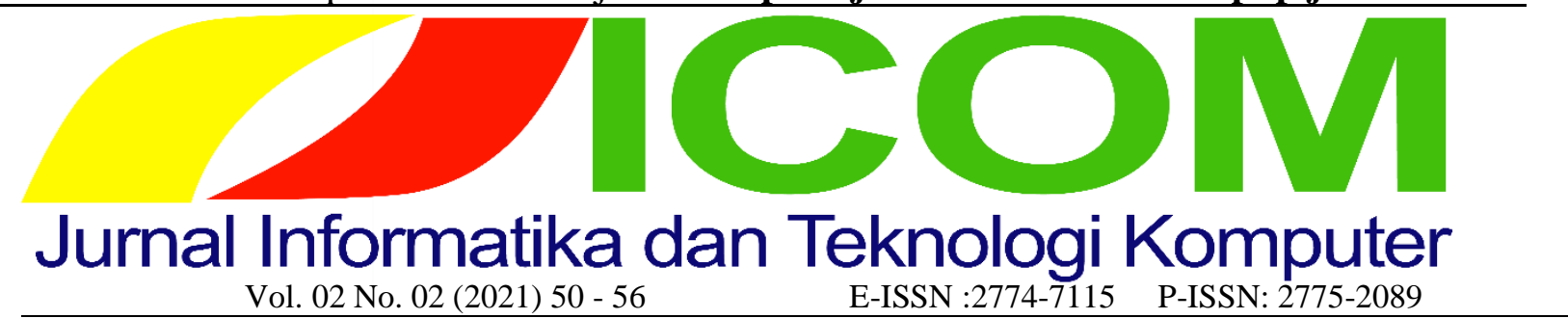

\title{
Analisis Sentimen Terhadapat Vaksin Covid-19 di Indonesia pada Twitter Menggunakan Metode Lexicon Based
}

\author{
Putri Amira Sumitro ${ }^{1}$, Rasiban $^{2 *}$, Dadang Iskandar Mulyana ${ }^{3}$, Wahyu Saputro ${ }^{4}$ \\ ${ }^{1}$ Jurusan Teknologi Informasi, STIKOM Cipta Karya Informatika \\ ${ }^{2}$ Jurusan Teknik Informatika, STIMIK Eresha* \\ ${ }^{3}$ Jurusan Teknologi Informasi, STIKOM Cipta Karya Informatika \\ ${ }^{4}$ Jurusan Teknologi Informasi, STIKOM Cipta Karya Informatika \\ ${ }^{1}$ putriamira567@gmail.com, ${ }^{2}$ Rasiban.Stikom@yahoo.com*, ${ }^{3}$ mahvin2012@gmail.com, ${ }^{4}$ wahyudahsyat@gmail.com
}

\begin{abstract}
Increasing the number of cases of Covid-19 in Indonesia, the Government of Indonesia has made various efforts in handling Covid-19, one of which is the policy of Covid-19 vaccine for all indonesian people. With this policy, many people express their opinions through Twitter. The purpose of this sentiment analysis research is to find out public opinion about the policy of vaccine covid-19 on Twitter whether the opinion falls into the class of sentiment that is categorized into 5 namely very positive sentiment, positive sentiment, negative sentiment, somewhat negative or neutral sentiment and know the accuracy of the percentage of each class of polarity. Lexicon based research method using vader sentiment library. Vader sentiment, which is a lexicon-based method of analysis based on rule-based sentiment analysis. Based on the accuracy of the percentage obtained by positive sentiment as much as $20.25 \%$, somewhat positive as much as $23.9 \%$, negative as much as $1.88 \%$, somewhat negative as much as $9.6 \%$ and neutral as much as $44.36 \%$. It can be concluded that public opinion on the Covid-19 vaccine on Twitter using lexicon-based methods by utilizing vader sentiment library is mostly neutral.
\end{abstract}

Keywords: sentiment analysis, covid-19 vaccine, twitter, lexicon based, vader sentiment.

\begin{abstract}
Abstrak
Meningkatnya jumlah kasus Covid-19 di Indonesia, pemerintah RI telah melakukan berbagai upaya dalam penanganan Covid19, salah satunya kebijakan vaksin Covid-19 untuk seluruh masyarakat indonesia. Dengan adanya kebijakan tersebut, banyak sekali masyarakat yang menyampaikan opininya melalui Twitter. Tujuan penelitian analisis sentimen ini untuk mengetahui opini masyarakat tentang kebijakan vaksin covid-19 pada twitter apakah opini tersebut masuk kedalam kelas sentimen yang di katagorikan menjadi 5 yaitu sentimen sangat positif, sentimen positif, sentimen negatif, sentimen agak negatif ataupun netral serta mengetahui hasil akurasi persentasi dari setiap kelas polaritas. Metode penelitian lexicon based menggunakan library vader sentiment. Vader sentiment, yaitu metode analisis lexicon-based berbasis rule-based sentiment analysis. Berdasarkan hasil akurasi persentase yang didapat sentimen positif sebanyak 20,25\%, agak positif sebanyak $23,9 \%$, negatif sebanyak $1,88 \%$, agak negatif sebanyak 9,6\% dan netral sebanyak 44,36\%. Dapat disimpulkan bahwa opini masyarakat terhadap vaksin Covid19 pada Twitter menggunakan metode lexicon based dengan memanfaatkan library vader sentiment kebanyakan adalah bersifat netral.
\end{abstract}

Kata kunci: analisis sentimen, vaksin covid-19, twitter, lexicon based, vader sentiment

\section{Pendahuluan}

Covid-19 merupakan penyakit yang disebabkan oleh virus severe acute respiratory syndrome coronavirus 2 (SARS-CoV-2). Menularnya Covid-19 membuat dunia menjadi resah, termasuk di Indonesia [1]. Total kasus Covid-19 di Indonesia per tanggal 26 Mei 2021 tercatat Positif 1.786.187 Sembuh 1.642.074 S 49.627[2].
Pada awal tahun 2021 pemerintah RI memulai program vaksin untuk mengurangi dampak pandemi yang semakin meningkat. Tujuan vaksinasi Covid-19 salah satunya meningkatkan kesehatan tubuh secara menyeluruh. Peraturan vaksin Covid-19 terdapat dalam Perpres No. 99 Tahun 2020 tentang Pengadaan Vaksin dan Pelaksanaan Vaksinasi Dalam Rangka Penanggulangan Pandemi COVID-19, Keputusan

Diterima Redaksi : 18-08-2021 | Selesai Revisi : 05-September-2021 | Diterbitkan Online : 15 - Oktober - 2021 
MenteriKesehatanNo.HK.01.02./MENKES/12758/202

1 tentang Penetapan Jenis Vaksin untuk Pelaksanaan Vaksinasi COVID-19, Permenkes No 84 Tahun 2020 Vader akan menganalisis text berdasarkan lexicon tentang Pelaksanaan Vaksinasi Dalam Rangka library) yang menghasilkan class sentiment berupa Penanggulangan Pandemi COVID19. Dengan adanya positif, negatif dan netral dengan tambahan skor total kebijakan pemerintah tentang pelaksanaan vaksin atau compound score [7].

Covid-19, sangat ramai dibicarakan dan menjadi trending topik di sosial media salah satunya, Twitter.

Tercatat sebanyak 19,5 juta pengguna Twitter di Indonesia [3] perihal ini menjadikan Twitter salah satu tempat untuk melakukan penelitian analisis sentimen ataupun opini mining untuk memahami dan mengolah data sehingga mengetahui informasi sentimen yang terdapat pada suatu kalimat opini. Analisis sentimen
digunakan untuk melihat pendapat opini pada seseorang, apakah opini tersebut postif, negatif ataupun netral.

Analisis sentimen adalah salah satu teknik dalam mengekstrak informasi berupa pandangan (sentimen) seseorang terhadap suatu isu atau kejadian. Analisis Sentimen dapat digunakan untuk mengungkap opini publik terhadap suatu isu, kepuasan pelayanan, kebijakan, cyber bulliying, memprediksi harga saham, dan analisis pesaing berdasarkan data tekstual [4]. Menganalisis tweet dapat menerapkan text mining. Text mining memberikan solusi pada masalah-masalah dalam memproses, mengorganisasi, dan menganalisa unstructured text dalam jumlah besar[5].

Penelitian ini bertujuan untuk menganalisis sentimen dari opini pengguna Twitter pada media sosial Twitter terhadap vaksin Covid-19 untuk mengelompokkan opini pengguna Twitter ke dalam kelas polaritas yang dikatagorikan menjadi sentimen positif, agak positif, negatif, agak negatif dan netral serta mengetahui hasil akurasi dari kelas polaritas masingmasing dengan metode lexicon based menggunakan library vader sentiment. Vader sentiment, yaitu metode analisis lexicon-based berbasis rule-based sentiment analysis. Data yang diambil bersumber dari sosial media Twitter sebanyak 1941 data dengan keywords "vaksin", "vaksin covid19", "vaksin gratis", "vaksin indonesia", "vaksin gotong royong".

\section{Metode Penelitian}

Dalam melakukan analisis sentimen ini metode yang digunakan adalah metode lexicon based menggunakan library vader sentiment. Menurut (Taboada, Brooke, Tofiloski, Voll, \& Stede, 2011) Lexicon Based adalah suatu proses pemilihan kata penting pada dokumen berdasarkan suatu kamus/leksikon yang sudah ada. Dalam pengaplikasiannya, terdapat dua buah kamus yang digunakan untuk menjadi wordlist. Kamus dengan kumpulan kata bersentimen positif dan kamus dengan kumpulan kata bersentimen negatif [6].
Vader Sentiment Lexicon merupakan salah satu kamus lexicon, kamus ini mempunyai 7.500 tokens yang mengandung kata berbahasa inggris emoticon serta sentimen yang terkait dengan akronim dan inisial [8].

Dalam jurnal (Hutto, C.J. \& Gilbert, E.E. 2014) penilaian analisis sentimen pada VADER dapat dikategorikan menjadi 4 bagian yaitu positif, negatif, netral, dan compound. nilai compound dihitung dengan menjumlahkan skor valensi setiap kata dalam leksikon, disesuaikan dengan aturan VADER, kemudian dinormalisasi menjadi antara -1 (negatif paling ekstrim) dan +1 (positif paling ekstrim). Nilai compound ini dapat digunakan sebagai satuan standar untuk mengklasifikasikan kalimat dengan ketentuan positif untuk compound $\geq 0.05$, negatif untuk compound $\leq-0.05$ dan netral untuk $-0.05<$ compound $<0.05$ [9].

Tahap penelitian terdiri dari tahap pengambilan data, preproccessing, translate, pengklasifikasian, visualisasi.

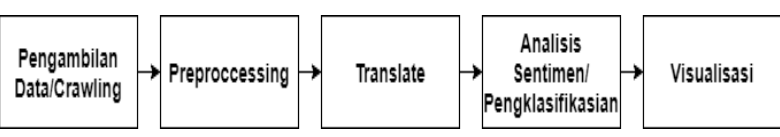

Gambar 1 Tahap Penelitian

\subsection{Pengambilan Data}

Langkah pertama pengambilan data yaitu dengan mempunyai akun Twitter, selanjutnya pembuatan akun Setelah itu barulah pengambilan data tweets dengan menggunakan search API Twitter. Data Keywords "vaksin", "vaksin covid19", "vaksin gratis", "vaksin indonesia", "vaksin gotong royong". Data yang terambil sebanyak 1941 tweets dalam bahasa Indonesia dimulai dari tanggal 19 Mei 2021 sampai tanggal 24 Mei 2021.

\subsection{Preproccessing}

Preproccessing bertujuan untuk seleksi data yang akan dilakukan pembersihan data tweet yang akan digunakan pada tahap Analisa sentimen / pengklasifikasian tweet. Proses preproccesing terdiri sebagai berikut:

1. Cleansing: Pada proses ini dilakukan untuk menghapus tanda baca serta karakter yang tidak penting seperti titik, koma, tanda seru, tanda tanya, menghilangkan URL dan HTML, menghapus emoji, mention dan hastag, serta menghilangkan simbol yang tidak relevan. developer Twitter untuk mendapatkan API Twitter. 
2. Case Folding: Pada proses ini mengubah 3.1. Pengambilan Data seluruh teks huruf dokumen menjadi huruf kecil.

Pengambilan data dengan API key Twitter sebanyak

3. Tokenization: Pada proses ini memisahkan sebuah teks menjadi potongan kata sebelum di analisa lebih lanjut

4. Filtering: Pada proses ini dilakukan untuk menghilangkan stop words atau bisa disebut kata-kata yang tidak memiliki makna agar lebih fokus terhadap kata-kata yang lebih bermakna.

5. Stemming: Pada proses ini mengubah kata berhimbunan menjadi kata dasar.

\subsection{Translate}

Setelah melakukan tahap preproccessing selanjutnya melakukan tahap translate. Pada tahap ini peneliti melakukan translate dari bahasa Indonesia ke bahasa Inggris karena peneliti akan menggunakan library vader sentiment dimana library tersebut menggunakan bahasa Inggris. Tahap ini dilakukan secara manual yaitu dengan menggunakan layanan translator di web yaitu Bing Translator dengan begitu web ini memiliki terjemahan bahasa inggris yang cukup baik.

\subsection{Analisis Sentimen/Pengklasifikasian}

Setelah melakukan tahap translate selanjutnya ke tahap pengklasifikasian tweet. Pada tahap ini dilakukan untuk melakukan labelling sentiment dan mengetahui score polarity. Metode yang digunakan adalah metode Lexicon Based, metode ini menggunakan kamus sebagai dasar bahasa atau leksikal. Hal ini memanfaatkan library python untuk score polarity kurang dari -0.5 adalah sentimen negatif, score polarity lebih dari -0,5 dan kurang dari 0 adalah sentimen agak negatif, score polarity 0 adalah sentimen netral, score polarity lebih dari 0 dan kurang dari 0,5 adalah sentimen agak positif, score polarity lebih besar dari 0,5 adalah sentimen positif.

\subsection{Visualisasi} 1941 tweet pada tanggal 19 Mei 2021 sampai 24 Mei 2021, dengan keywords "vaksin $O R$ vaksin covid $O R$ vaksin covid19 $O R$ vaksin gratis $O R$ vaksin Indonesia $O R$ vaksin gotong royong". Setelah data tweet terambil, data tersebut diubah menjadi data frame agar mudah diproses pada tahap berikutnya. Data frame berisi 3 atribut, atribut-atribut tersebut adalah:

1. Username: username berisi nama akun dari penulis atau pembuat tweet tersebut.

2. Tweetcreatedts: tweetcreatedts berisi tanggal dan waktu kapan dibuatnya tweet tersebut.

3. Teks: teks berisi isi tweet tersebut.

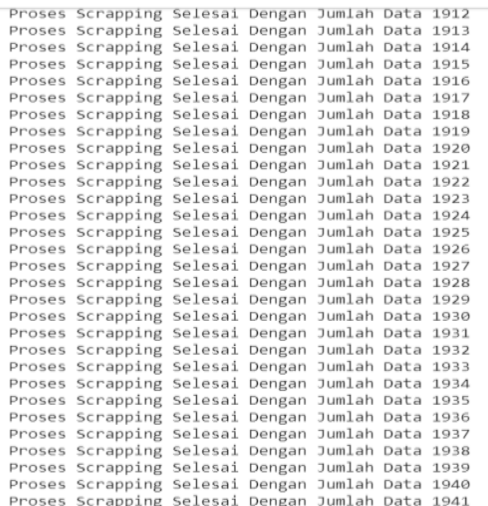

Gambar 2 Hasil Pengambilan Data API Key Twitter

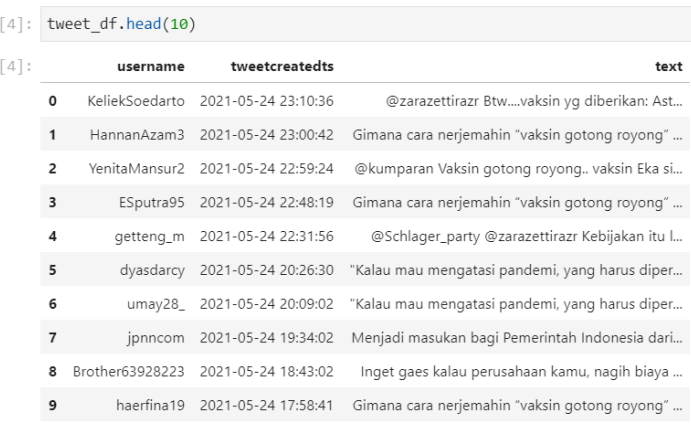

Gambar 3 Hasil Data Diubah Menjadi Data Frame

Setelah semua selesai selanjutnya tahap visualisasi, 3.2. Preproccessing

pada tahap ini peneliti menggunakan library matplotlib. Gambaran yang ditampilkan berbentuk histogram dan menapilkan hasil akurasi persentase yang dihasilkan dari setiap kelas polaritas.

\section{Hasil dan Pembahasan}

Pada tahap ini akan dilakukan cleansing, case folding, tokenization, filtering, stemming. Proses tahap ini dilakukan untuk penghapusan tanda baca serta karakter yang tidak penting seperti titik, koma, tanda seru, tanda tanya, menghilangkan URL dan HTML, menghapus emoji, mention dan hastag, serta

Pengambilan data dari Twitter menggunakan API menghilangkan simbol yang tidak relevan, mengubah key Twitter maka dari itu peneliti harus mempunyai key seluruh teks huruf dokumen menjadi huruf kecil, number dan secret number dari API key Twitter dengan memisahkan sebuah teks, menghilangkan stop words, cara mengakses https://developer.twitter.com dan mengubah kata berhimbunan menjadi kata dasar. mendaftar untuk melakukan pengajuan kepada pihak developer untuk mendapatkan API key Twitter.

\subsubsection{Cleansing}

Pada proses ini untuk menghapus seperti karater “@”, link URL, titik, koma, tanda seru, tanda 
tanya, menghapus emoji, mention dan hastag, serta menghilangkan simbol yang tidak relevan.

\begin{tabular}{|c|c|}
\hline Sebelum & Sesudah \\
\hline $\begin{array}{l}\text { @ } \text { zarazettirazr } \\
\text { Btw....vaksin yg diberikan: } \\
\text { Astrazeneca, Fifzer, } \\
\text { Moderna.....mungkin itu } \\
\text { yg dimaksud vaksin } \\
\text { gotong royong.... }\end{array}$ & $\begin{array}{l}\text { Btw vaksin yg } \\
\text { diberikan } \\
\text { Fstrazeneca } \\
\text { Fifzer } \quad \text { Moderna } \\
\text { mungkin itu yg } \\
\text { dimaksud } \quad \text { vaksin } \\
\text { gotong royong }\end{array}$ \\
\hline $\begin{array}{l}\text { Gimana cara nerjemahin } \\
\text { "vaksin gotong royong" ke } \\
\text { dalam bahasa Inggris? } \\
\text { a }-\theta \text {, disini cuma } \\
\text { ada satu vaksin which is } \\
\text { Free Vaccine } \theta-\theta) \\
\text { Vaksin gotong royong = } \\
\text { togetherness vaccine? Apa } \\
\text { gimana wakakaka }\end{array}$ & $\begin{array}{l}\text { Gimana } \\
\text { nerjemahin vara } \\
\text { gotong royong ke } \\
\text { dalam bahasa Inggris } \\
\text { disini cuma ada satu } \\
\text { vaksin which is Free } \\
\text { Vaccine } \\
\text { gotong Vaksin } \\
\text { togetherness } \\
\begin{array}{ll}\text { Apa } & \text { royong } \\
\text { wakakaka } & \text { gimana }\end{array}\end{array}$ \\
\hline $\begin{array}{ll}\text { @ kumparan } & \text { Vaksin } \\
\text { gotong royong.. } & \text { vaksin } \\
\text { Eka sila donk? - } & \end{array}$ & $\begin{array}{l}\text { Vaksin gotong royong } \\
\text { vaksin Eka sila donk }\end{array}$ \\
\hline $\begin{array}{l}\text { @ Schlager_party } \\
@ \text { zarazettirazr Kebijakan } \\
\text { itu luar biasa. Gotong } \\
\text { royong = privat (transaksi } \\
\text { jual beli). Penyesatan } \\
\text { makna kata. Atau } \\
\text { pemerintah malu2 saja } \\
\text { untuk tdk katakatan } \\
\text { privatisasi vaksin. Sama } \\
\text { halnya BPJS, esensinya } \\
\text { gotong } \\
\text { royong,prakteknya,spt } \\
\text { debtcollector. }\end{array}$ & $\begin{array}{l}\text { Kebijakan itu luar } \\
\text { biasa. Gotong royong } \\
\text { privat transaksi jual } \\
\text { beli Penyesatan } \\
\text { makna kata Atau } \\
\text { pemerintah malu saja } \\
\text { untuk tdk katakatan } \\
\text { privatisasi vaksin } \\
\text { Sama halnya BPJS } \\
\text { esensinya gotong } \\
\text { royong prakteknyaspt } \\
\text { debtcollector }\end{array}$ \\
\hline
\end{tabular}

\subsubsection{Case Folding}

Pada proses ini huruf data tweet yang sudah di bersihkan tidak sama, dengan case folding membuat data tweet menjadi lowercase atau huruf kecil agar mudah pembacaan dalam komputer.

Tabel 2 Data Case Folding

\begin{tabular}{|l|l|}
\hline Sebelum & Sesudah \\
\hline Btw vaksin yg diberikan & btw vaksin yg diberikan \\
Astrazeneca Fifzer & $\begin{array}{l}\text { astrazeneca fifzer } \\
\text { moderna mungkin itu }\end{array}$ \\
\hline
\end{tabular}

\begin{tabular}{|c|c|}
\hline $\begin{array}{l}\text { dimaksud vaksin gotong } \\
\text { royong }\end{array}$ & $\begin{array}{l}\text { yg dimaksud vaksin } \\
\text { gotong royong }\end{array}$ \\
\hline $\begin{array}{l}\text { Gimana cara nerjemahin } \\
\text { vaksin gotong royong ke } \\
\text { dalam bahasa Inggris } \\
\text { disini cuma ada satu } \\
\text { vaksin which is Free } \\
\text { Vaccine Vaksin gotong } \\
\text { royong togetherness } \\
\text { vaccine Apa gimana } \\
\text { wakakaka }\end{array}$ & $\begin{array}{l}\text { gimana cara nerjemahin } \\
\text { vaksin gotong royong } \\
\text { ke dalam bahasa inggris } \\
\text { disini cuma ada satu } \\
\text { vaksin which is Free } \\
\text { vaccine vaksin gotong } \\
\text { royong togetherness } \\
\text { vaccine apa gimana } \\
\text { wakakaka }\end{array}$ \\
\hline $\begin{array}{l}\text { Vaksin gotong royong } \\
\text { vaksin Eka sila donk }\end{array}$ & $\begin{array}{l}\text { vaksin gotong royong } \\
\text { vaksin eka sila donk }\end{array}$ \\
\hline $\begin{array}{l}\text { Kebijakan itu luar biasa. } \\
\text { Gotong royong privat } \\
\text { transaksi jual beli } \\
\text { Penyesatan makna kata } \\
\text { Atau pemerintah malu } \\
\text { saja untuk tdk katakatan } \\
\text { privatisasi vaksin Sama } \\
\text { halnya BPJS esensinya } \\
\text { gotong royong } \\
\text { prakteknyaspt } \\
\text { debtcollector }\end{array}$ & $\begin{array}{l}\text { kebijakan itu luar biasa. } \\
\text { gotong royong privat } \\
\text { transaksi jual beli } \\
\text { Penyesatan makna kata } \\
\text { atau pemerintah malu } \\
\text { saja untuk tdk katakatan } \\
\text { privatisasi vaksin Sama } \\
\text { halnya bpjs esensinya } \\
\text { gotong royong } \\
\text { prakteknyaspt } \\
\text { debtcollector }\end{array}$ \\
\hline
\end{tabular}

\subsubsection{Remove Stopwords}

Pada proses ini menggunakan library NLTK bahasa Indonesia untuk mempermudah proses remove stopwords. Peneliti juga menambahkan beberapa kata yang sering muncul pada data tweet seperti "yg", "utk", "tdk" dan lainnya agar meminimalisir terjadinya noise dan membuat data lebih bersih.

Tabel 3 Data Remove Stopwords

\begin{tabular}{|c|c|}
\hline Sebelum & Sesudah \\
\hline $\begin{array}{l}\text { btw vaksin yg diberikan } \\
\text { astrazeneca } \\
\text { moderna mungkin itu yg } \\
\text { dimaksud vaksin gotong } \\
\text { royong }\end{array}$ & $\begin{array}{l}\text { vaksin astrazeneca } \\
\text { fifzer moderna vaksin } \\
\text { gotong royong }\end{array}$ \\
\hline $\begin{array}{l}\text { gimana cara nerjemahin } \\
\text { vaksin gotong royong ke } \\
\text { dalam bahasa inggris } \\
\text { disini cuma ada satu } \\
\text { vaksin which is Free } \\
\text { vaccine vaksin gotong } \\
\text { royong togetherness } \\
\text { vaccine apa gimana } \\
\text { wakakaka }\end{array}$ & $\begin{array}{l}\text { gimana vaksin gotong } \\
\text { royong bahasa inggris } \\
\text { vaksin which is Free } \\
\text { vaccine vaksin gotong } \\
\text { royong togetherness } \\
\text { vaccine gimana }\end{array}$ \\
\hline
\end{tabular}




\begin{tabular}{|c|c|}
\hline $\begin{array}{l}\text { vaksin gotong royong } \\
\text { vaksin eka sila donk }\end{array}$ & $\begin{array}{l}\text { vaksin gotong royong } \\
\text { vaksin eka sila }\end{array}$ \\
\hline $\begin{array}{l}\text { kebijakan itu luar biasa } \\
\text { gotong royong privat } \\
\text { transaksi jual beli } \\
\text { Penyesatan makna kata } \\
\text { atau pemerintah malu saja } \\
\text { untuk tdk katakatan } \\
\text { privatisasi vaksin Sama } \\
\text { halnya bpjs esensinya } \\
\text { gotong } \\
\text { prakteknyaspt } \\
\text { debtcollector }\end{array}$ & $\begin{array}{lr}\text { kebijakan } & \text { gotong } \\
\text { royong privat transaksi } \\
\text { jual beli } & \text { penyesatan } \\
\text { makna } & \text { pemerintah } \\
\text { malu } & \text { katakatan } \\
\text { privatisasi } & \text { vaksin } \\
\text { halnya bpjs } & \text { esensinya } \\
\text { gotong } & \text { royong } \\
\text { prakteknyaspt } & \\
\text { debtcollector } & \end{array}$ \\
\hline
\end{tabular}

\subsubsection{Tokenization}

Pada proses ini peneliti menggunakan library NLTK khusus untuk tokenize tweet. Proses ini untuk memecah suatu teks menjadi beberapa bagian, bagiannya bisa berupa kata atau kalimat.

Tabel 4 Data Tokenization

\begin{tabular}{|c|c|}
\hline Sebelum & Sesudah \\
\hline $\begin{array}{l}\text { vaksin astrazeneca } \\
\text { fifzer moderna vaksin } \\
\text { gotong royong }\end{array}$ & $\begin{array}{l}\text { [vaksin, astrazeneca, } \\
\text { fifzer, moderna, vaksin, } \\
\text { gotong, royong] }\end{array}$ \\
\hline $\begin{array}{l}\text { gimana vaksin gotong } \\
\text { royong bahasa inggris } \\
\text { vaksin which is Free } \\
\text { vaccine vaksin gotong } \\
\text { royong togetherness } \\
\text { vaccine gimana }\end{array}$ & $\begin{array}{l}\text { [gimana, vaksin, gotong, } \\
\text { royong, bahasa, inggris, } \\
\text { vaksin, which, is, free, } \\
\text { vaccine, vaksin, gotong, } \\
\text { royong, togetherness, } \\
\text { vaccine, gimana] }\end{array}$ \\
\hline $\begin{array}{l}\text { vaksin gotong royong } \\
\text { vaksin eka sila }\end{array}$ & $\begin{array}{l}\text { [vaksin, gotong, royong, } \\
\text { vaksin, eka, sila] }\end{array}$ \\
\hline $\begin{array}{l}\text { kebijakan gotong } \\
\text { royong privat transaksi } \\
\text { jual beli penyesatan } \\
\text { makna pemerintah malu } \\
\text { katakatan privatisasi } \\
\text { vaksin halnya bpjs } \\
\text { esensinya gotong } \\
\text { royong prakteknyaspt } \\
\text { debtcollector }\end{array}$ & $\begin{array}{l}\text { [kebijakan, } \text { gotong, } \\
\text { royong, privat, transaksi, } \\
\text { jual, beli, penyesatan, } \\
\text { makna, r pemerintah, } \\
\text { malu, } \\
\text { privatisasi, } \\
\text { halnya, bpjs, esensinya, } \\
\text { gotong, } \\
\text { prakteknyasin, } \\
\text { debtcollector] }\end{array}$ \\
\hline
\end{tabular}

\subsubsection{Stemming}

Proses stemming menggunakan library stemmer factory. Tujuan dilakukannya stemming yaitu menemukan kata dasar dari suatu kalimat data tweet dan mengapus kata himbuan yang terdapat pada awalan, sisipan, atau akhiran kata.

\begin{tabular}{|c|c|}
\hline Sebelum & Sesudah \\
\hline $\begin{array}{l}\text { vaksin astrazeneca fifzer } \\
\text { moderna vaksin gotong royong }\end{array}$ & $\begin{array}{l}\text { vaksin astrazeneca fifzer } \\
\text { moderna vaksin gotong } \\
\text { royong }\end{array}$ \\
\hline $\begin{array}{l}\text { gimana vaksin gotong royong } \\
\text { bahasa inggris vaksin which is } \\
\text { Free vaccine vaksin gotong } \\
\text { royong togetherness vaccine } \\
\text { gimana }\end{array}$ & $\begin{array}{l}\text { gimana } \text { vaksin gotong } \\
\text { royong bahasa inggris } \\
\text { vaksin which is Free } \\
\text { vaccine vaksin gotong } \\
\text { royong togetherness } \\
\text { vaccine gimana }\end{array}$ \\
\hline $\begin{array}{l}\text { vaksin gotong royong vaksin } \\
\text { eka sila }\end{array}$ & $\begin{array}{l}\text { vaksin gotong royong } \\
\text { vaksin eka sila }\end{array}$ \\
\hline $\begin{array}{l}\text { kebijakan gotong royong privat } \\
\text { transaksi jual beli penyesatan } \\
\text { makna pemerintah malu } \\
\text { katakatan privatisasi vaksin } \\
\text { halnya bpjs esensinya gotong } \\
\text { royong prakteknyaspt } \\
\text { debtcollector }\end{array}$ & $\begin{array}{l}\text { bijak gotong royong privat } \\
\text { transaksi jual beli sesat } \\
\text { makna pemerintah malu } \\
\text { katakatan privatisasi } \\
\text { vaksin hal bpjs esensi } \\
\text { gotong } \\
\text { prakteknyaspt royong } \\
\text { debtcollector }\end{array}$ \\
\hline
\end{tabular}

\subsection{Translate}

Setelah data dibersihkan pada tahap preproccessing, selanjutnya melakukan tahap translate data menggunakan layanan translate di web yaitu Bing Translator. Tahap ini dilakukan secara manual dengan menerjamahkannya satu persatu.

\begin{tabular}{|c|c|}
\hline Sebelum & Sesudah \\
\hline $\begin{array}{lr}\text { vaksin } & \text { astrazeneca } \\
\text { fifzer } & \text { moderna } \\
\text { vaksin } & \text { gotong } \\
\text { royong } & \end{array}$ & $\begin{array}{l}\text { astrazeneca fifzer moderna } \\
\text { vaccine mutual cooperation }\end{array}$ \\
\hline \begin{tabular}{lr} 
gimana & vaksin \\
gotong & royong \\
bahasa & inggris \\
vaksin which is Free & vaccine $\quad$ vaksin \\
gotong royong & rogetherness \\
\multicolumn{2}{l}{ vaccine gimana }
\end{tabular} & $\begin{array}{l}\text { how is the mutual } \\
\text { cooperation vaccine in } \\
\text { english which is free vaccine } \\
\text { how is the mutual } \\
\text { cooperation } \\
\text { togetherness vaccine }\end{array}$ \\
\hline \begin{tabular}{lr} 
vaksin & \multicolumn{2}{c}{ gotong } \\
royong & vaksin eka \\
sila &
\end{tabular} & $\begin{array}{l}\text { mutual cooperation vaccine } \\
\text { eka sila }\end{array}$ \\
\hline
\end{tabular}




\begin{tabular}{l|lr} 
bijak gotong royong & wise private mutual \\
privat transaksi jual & cooperation deviant buying \\
beli sesat makna & and selling transactions the \\
pemerintah malu & meaning of the the \\
katakatan privatisasi & commandment shame the \\
vaksin hal bpjs & words privatization of \\
esensi gotong & vaccines the bpjs matter the \\
royong & essence of mutual \\
prakteknyaspt & cooperation in practice such \\
debtcollector & as debt collectors
\end{tabular}

\subsection{Analisis Sentimen/Pengklasifikasian}

Metode yang digunakan adalah Lexicon Based, metode ini menggunakan kamus sebagai dasar bahasa atau leksikal. Dasar penentuan sementara untuk kelas polaritas dan score polarity menggunakan vader sentiment. Score polarity kurang dari -0.5 adalah sentimen negatif, score polarity lebih besar dari -0,5 dan kurang dari 0 adalah sentimen agak negatif, score polarity 0 adalah sentimen netral, score polarity lebih dari 0 dan kurang dari 0,5 adalah sentimen agak positif, score polarity lebih besar dari 0,5 adalah sentimen positif.

\begin{tabular}{|l|l|l|}
\hline Tweet & $\begin{array}{l}\text { Score } \\
\text { polarity }\end{array}$ & Sentiment \\
\hline $\begin{array}{l}\text { astrazeneca fifzer moderna } \\
\text { vaccine mutual cooperation }\end{array}$ & 0,0 & Netral \\
\hline $\begin{array}{l}\text { how is the mutual } \\
\text { cooperation vaccine in } \\
\text { english which is free vaccine } \\
\text { how is the mutual } \\
\text { cooperation vaccine } \\
\text { togetherness vaccine }\end{array}$ & 0,5106 & Positif \\
\hline $\begin{array}{l}\text { no vaccines gotong royong } \\
\text { don pay mutual }\end{array}$ & -0.3818 & $\begin{array}{l}\text { Agak } \\
\text { Negatif }\end{array}$ \\
\hline $\begin{array}{l}\text { vaccines } \\
\text { cooperation efforts to protect } \\
\text { the nation s economy will } \\
\text { recover }\end{array}$ & $\begin{array}{l}\text { Agak } \\
\text { Positif }\end{array}$ \\
\hline
\end{tabular}

\subsection{Visualisasi}

Setelah semua tahapan telah diselesaikan maka divisualisasi untuk mengetahui hasil akurasi persentase dari kelas polaritas masing-masing. Hasil akurasi persentase yang didapat yaitu sebesar $44,36 \%$ untuk hasil akurasi persentase kelas sentimen netral, 23,9\% untuk hasil akurasi persentase kelas sentimen agak positif, 20,25\% untuk hasil akurasi persentase kelas sentimen positif, 9,6\% untuk hasil akurasi persentase kelas sentimen agak negatif, 1,88\% untuk hasil akurasi persentase kelas sentimen negatif. Hasil visualisasi ditampilkan dalam bentuk histogram.

\section{Gambar 4 Hasil Visualisasi Histogram}

\section{Kesimpulan}

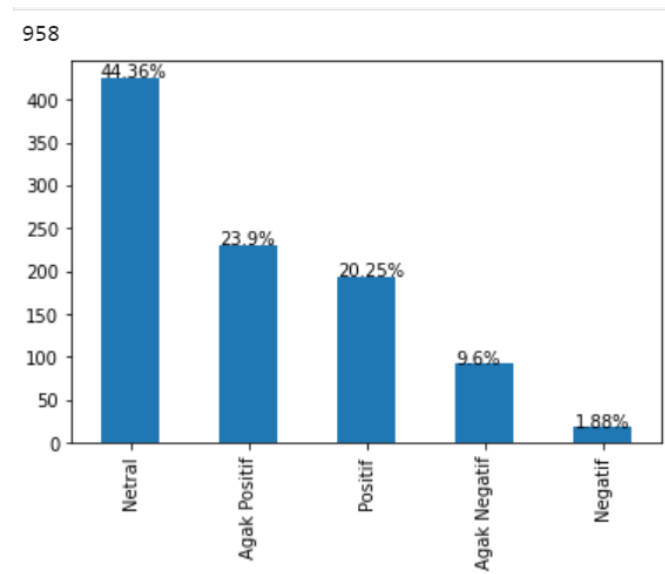

Analisis sentimen terhadap vaksin Covid-19 menggunakan data yang bersumber dari sosial media Twitter sebanyak 1941 data tweet. Tweet tersebut diolah lalu pengklasifikasian menggunakan metode lexicon based dengan memanfaatkan library vader sentiment, maka hasil yang didapat sentimen positif sebanyak $20,25 \%$, agak positif sebanyak $23,9 \%$, negatif sebanyak $1,88 \%$, agak negatif sebanyak $9,6 \%$ dan netral sebanyak $44,36 \%$. Dapat disimpulkan bahwa opini masyarakat terhadap vaksin Covid-19 pada Twitter lebih cenderung netral..

\section{Daftar Rujukan}

[1] D. Telaumbanua, "Urgensi Pembentukan Aturan Terkait Pencegahan Covid-19 di Indonesia," QALAMUNA J. Pendidikan, Sos. dan Agama, vol. 12, no. 01, pp. 59-70, 2020, doi: 10.37680/qalamuna.v12i01.290.

"Beranda Covid19.go.id." https://covid19.go.id/ (accessed May 27, 2021).

[3] "Kementerian Komunikasi dan Informatika." https://kominfo.go.id/content/detail/2366/ indonesia-peringkat-limapenggunatwitter/0/sorotan_media (accessed May 27, 2021).

[4] W. Setianto, “Analisis Sentimen Twitter Untuk Mengetahui Dampak Dari Pandemi Covid-19 Terhadap Masyarakat Jakarta," Github, pp. 117, 2020, [Online]. Available: 
https://github.com/Hyuto/Analisis-SentimenCorona-DKI-Jakarta ABSTRAK.

[5] I. Adiwijaya, "Text Mining dan Knowledge Discovery," Kolok. bersama komunitas datamining Indones. soft-computing Indones., pp. 1-9, 2006, [Online]. Available: http://web.ipb.ac.id/ ir-lab/pdf/tm

(text [8] summarization).pdf.

[6] N. S. Fathullah, Y. A. Sari, and P. P. Adikara, "Analisis Sentimen Terhadap Rating dan Ulasan Film dengan menggunakan," J. Pengemb. Teknol. Inf. dan Ilmu Komput., vol. 4, no. 2, pp. [9] 590-593, 2020.

[7] N. Anggraini, S. Kom, H. Suroyo, and M. Kom, "Comparison of Sentiment Analysis against
Digital Payment ' $\mathrm{T}$-cash and Go- pay' in Social Media Using Orange Data Mining Perbandingan Analisis Sentimen Terhadap Digital Payment ' $\mathrm{T}$-cash dan Go- pay' Di Sosial Media Menggunakan Orange Data Mining," vol. 1, no. 1, pp. 152-163, 2019.

B. Y. Melani, S. R. Wardhana, and D. Puspita, "Analisa Kualitas Fitur Aplikasi Mobile Dengan Menggunakan Pendekatan Sentimen Grey," Semin. Nas. Sains dan Teknol. Terap., vol. VII, 2019.

R. A. Fathurrahman, "Analisis Sentimen Pasar Saham dari Berita Keuangan menggunakan Algoritma Pencocokan String," no. 13519113, 2021. 
Putri Amira Sumitro ${ }^{1}$ Rasiban $^{2 *}$, Dadang Iskandar Mulyana ${ }^{3}$, Wahyu Saputro ${ }^{4}$ Jurnal J-COM (Jurnal Informatika dan Teknologi Komputer) Vol. 02 No. 02 (2021) 50 - 56

Jurnal J-COM (Jurnal Informatika dan Teknologi Komputer) Vol. 02 No. 01 (2021) 50 - 56 